\title{
Nitrogen Fertilizer and Panicle Removal in Sweet Sorghum Production: Effect on Biomass, Juice Yield and Soluble Sugar Content
}

\author{
Maru K. Kering, Vitalis W. Temu, Laban K. Rutto \\ Virginia State University Agriculture Research Station, Petersburg, VA, USA \\ Email: mkering@vsu.edu
}

How to cite this paper: Kering, M.K., Temu, V.W. and Rutto, L.K. (2017) Nitrogen Fertilizer and Panicle Removal in Sweet Sorghum Production: Effect on Biomass, Juice Yield and Soluble Sugar Content. Journal of Sustainable Bioenergy Systems, 7, 14-26.

https://doi.org/10.4236/jsbs.2017.71002

Received: January 18, 2017

Accepted: February 10, 2017

Published: February 13, 2017

Copyright (๑ 2017 by authors and Scientific Research Publishing Inc. This work is licensed under the Creative Commons Attribution International License (CC BY 4.0).

http://creativecommons.org/licenses/by/4.0/

\begin{abstract}
Alternative and renewable bio-based energy sources are gaining prominence worldwide. Sweet sorghum is currently being evaluated throughout the world because its stem juices are rich in sugars that can be directly fermented to ethanol. In this two-year study, sweet sorghum varieties; Dale, Theis, Topper 76-6, and M81E (Obtained from Mississippi State University Experiment Station, MS) and CHR-SW8 (Obtained from Chromatin Inc., IL) were used. Nitrogen $(\mathrm{N})$ fertilizer rates of $0,40,80$ or $120 \mathrm{~kg} \cdot \mathrm{N} \cdot \mathrm{ha}^{-1}$ were applied to experimental units. The experiment was a randomized complete block design with treatments in a split-split plot arrangement with three replications. Nitrogen rate was the main plot, cultivar as sub-plot, and panicle removal as sub-plot. Results showed that $\mathrm{N}$ application increased fresh stem yield, juice volume, but had minimal effect on juice soluble sugar concentration. Compared to controls, application of $\geq 40 \mathrm{~kg} \cdot \mathrm{N} \cdot \mathrm{ha}^{-1}$ increased fresh yield and juice by $>60 \%$ and $10 \%$, respectively. There were also variety differences in harvested fresh biomass, juice volume and ${ }^{\circ} \mathrm{Brix}$, and soluble sugar content. Dale and Theis consistently showed lower sucrose compared to other varieties over the two years. Panicle removal during early reproductive phase increased ${ }^{\circ} \mathrm{Brix}$, sucrose and total sugar content in all varieties. Across the two years of study, panicle removal increased ${ }^{\circ}$ Brix by more than $10 \%$, sucrose and total sugar increased by more than $20 \%$. Selection of varieties that produce high juice volume with high sugar content and strategies to inhibit seed formation may result in improved juice quality.
\end{abstract}

\section{Keywords}

Sweet Sorghum, Juice, Sugar, Panicle, Nitrogen

\section{Introduction}

Throughout the world, there is increasing attention to bio-based renewables as 
alternatives to fossil-based energy sources. Given the wide variety of crop with potential bioenergy use, there is a need for well researched scientific information on production of different bio-energy crops. Sorghum is a warm-season grass species that tolerates both high temperatures and moisture stress conditions. Its distinct morphological characteristics make it suitable for production in areas where other grass family crops like maize do poorly [1]. Sorghum's extensive root system allows a large volume of soil to be sampled for moistures and its small waxy leaves limit water loss through evapo-transpiration. Under low soil moisture, sorghum is reported to maintain physiological activity by increasing root length density and water-use efficiency [2]. Sweet sorghum whose stems contain high content of easily fermentable sugars [3] [4] [5] [6] is being evaluated, worldwide, as a source of sugar-rich juices for bio-ethanol production. When compared to other grasses like switchgrass, big bluestem, and miscanthus, sweet sorghum produced the highest estimated biomass and ethanol yield [7]. Sweet sorghum is also reported to produce $23 \%$ more fermentable sugars, requiring $37 \%$ less nitrogen $(\mathrm{N})$ fertilizer, and $17 \%$ less irrigation water than maize [8]. It is also reported to produce more ethanol than maize during dry periods [9]. Unlike sugarcane, a crop with sugar-rich stems too, sweet sorghum is ready for harvest in a single season and gives better returns on unit area basis [6] [10] [11]. The concentration of sucrose and the dominant fermentable sugars in all sweet sorghum differ with varieties [8] [10]. Variety selection and field management approaches like de-heading affect stem sugar concentration [12] [13]. These differences in juice sugar concentration and juice volume may be responsible for reported variation in ethanol yields among sweet sorghum cultivars [9] [12] [14] [15]. Acid hydrolysis of bagasse, a left-over product of juice extraction, releases more sugars for fermentation [16]. Bagasse can also be burned to provide heat and electrical energy [5] [17].

Sweet sorghum has been grown extensively for syrup in the southeastern states in the United State of America [18]. While the crop can tolerate poorly drained soils, and yields are highest in well drained loam or sandy loam soils. Studies in the southern states have reported sweet sorghum production for ethanol to be economically viable, and yields of between 3700 and $5600 \mathrm{~L} \cdot \mathrm{ha}^{-1}$ have been reported in Florida [19]. Fertilizer requirements depend on soil test fertility levels and preceding crop, but in well drained silt loam, $45 \mathrm{~kg} \cdot \mathrm{ha}^{-1}$ each of $\mathrm{N}, \mathrm{P}_{2} \mathrm{O}_{5}$, and $\mathrm{K}_{2} \mathrm{O}$ is sufficient [18]. Other field management strategies affect sweet sorghum fresh biomass, juice yield and sugar content, and bagasse quantity and quality. A study on M81-E showed that both $\mathrm{N}$ fertilizer rate and soil types are important [20]. The wide genetic variability and varying responses to similar environmental and management conditions call for an evaluation of varieties to determine their productivity potential in given localities.

While such production incentives may exist, there is lack of recommendations and cropping guidelines for sweet sorghum due to insufficient research in the mid-Atlantic. There is need for a comprehensive study to determine the suitability of sweet sorghum cultivars to prevailing climatic and edaphic conditions. The 
objective of this study was to evaluate the effect of nitrogen fertilizer and beheading on biomass production, extractable juice, and juice sugar content of five sweet sorghum cultivars in mid-central Virginia.

\section{Materials and Methods}

\subsection{Experimental Design and Treatment}

Sorghum was planted in clean-tilled plots at Virginia State University Demonstration and Research Farm (Randolph Farm), near Ettrick, VA $\left(37^{\circ} 13^{\prime \prime} 43^{\prime} \mathrm{N}\right.$; $77^{\circ} 26^{\prime \prime} 22^{\prime} \mathrm{W}$, elevation $45 \mathrm{~m}$ above sea level). Temperature and rainfall from April through October of each production year is shown in Table 1. The soil type at the site is a Bourne series fine sandy loam (mixed, semi-active, thermic Typic Fragiudults). The experiment was laid out as a randomized complete block design with treatments in a split-split plot arrangement, and replicated three times. Nitrogen rate was the main plot, cultivar the sub-plot, and head panicle presence/absence (head removal) the sub-sub-plot treatment. During planting in late spring (May 30, 2014 and May 27, 2015), seeds at a rate that results in about 89,000 plant ha $^{-1}$ were drilled in four rows, $45 \mathrm{~cm}$ apart, in $1.8 \mathrm{~m} \mathrm{x} 4.5 \mathrm{~m}$ experimental plots. With each plot replicated three times. Phosphorus and $\mathrm{K}$ application was incorporated prior to planting based on soil test recommendations. Nitrogen fertilizer at $0,40,80$, or $120 \mathrm{~kg} \cdot \mathrm{N} \cdot \mathrm{ha}^{-1}$ was applied at the 3 - 4 leaf-stage. No irrigation was done and weed control was by a combination of pre-emergent herbicide application and post-emergent tilling. At the beginning of panicle emergence and early milk stage, plants in plots to be de-headed had their panicles physically removed. The other plots had the panicle intact until harvested. The sweet sorghum varieties used were; Dale, Theis, Topper 76-6 and M81E (MAFES Foundation Seed Stocks, Mississippi State University, MS) and CHRSW8 (Chromatin Inc., IL).

\subsection{Data Collection}

\subsubsection{Fresh Stem Biomass}

Stems for yield determination were obtained from a randomly selected middle row. All plants within a given length in the middle of the selected row were harvested and separated in to leaves and stems (stems + sheath). Leave and stem

Table 1 . Monthly precipitation and mean temperature during crop growth period near Randolph farm, Virginia State University.

\begin{tabular}{ccccccccc}
\hline Production year & Apr & May & Jun & Jul & Aug & Sep & Oct & Mean values \\
\hline \multirow{2}{*}{2014} & 102.9 & 62.0 & 86.1 & 66.8 & 91.6 & 34.3 & 66.8 & 510.5 \\
2015 & 135.4 & 40.9 & 150.1 & 149.6 & 70.4 & 87.1 & 82.3 & 715.8 \\
& & & & Tecipitation $(\mathrm{mm})$ \\
2014 & 14.4 & 20.9 & 24.8 & 25.9 & 25.0 & 23.2 & 17.9 & 21.7 \\
2015 & 15.1 & 21.4 & 25.9 & 26.9 & 25.7 & 24.3 & 17.1 & 22.3 \\
\hline
\end{tabular}


fresh weights were determined and leaf dry weight determined after oven drying to constant weight. Total leaf biomass (leaf $\mathrm{DM} \mathrm{ha}^{-1}$ ) was calculated based on the expected fresh weight yield per hectares (fresh biomass ha ${ }^{-1}$ ).

\subsubsection{Juice Extraction and Volume Measurement}

Representative stems were selected for juice extraction, and separated into bottom, middle, and top sections. Each sub-section was processed independently for juice extraction and the extracted juice was collected in a jar and volume determined using a calibrated measuring cylinder. Juice was extracted using a stainless steel RAJA-SS sugarcane juice extracting machine (US Ice Machine Manufacturing Company, North Miami FL). Total juice volume per stem was obtained as a sum of the individual volumes of the three stem sections. Juice yield per experimental plot and the expected volume on hectare basis was calculated based on plot stem fresh weight (stems + sheath) harvested from each plot, and expected total fresh biomass per hectare (fresh weight ha ${ }^{-1}$ ).

\subsubsection{Juice Brix and Sugar Content Determination}

Juice from each stem section was analyzed independently for brix and sugar content. After determining the volume of extracted juice, the juice brix was determined using a digital hand-held MASTER-20 alpha pocket refractometer (Atago, Tokyo, Japan) on a subsample drawn from the extract. Juice samples were analyzed for soluble sugar (Glucose, fructose, and sucrose) contents using HPLC method optimized by Johansen et al. [21]. Sugars in the extracts were identified by comparing their retention times with standard sugars. For quantification, trehalose was used as an internal standard and sugar concentration was expressed as a percentage of juice volume. The sum of these individual soluble sugars was considered as total fermentable soluble sugars, an approach previously used by other researchers [22] [23].

Data was analyzed using mixed (PROC MIXED) procedures in SAS 9.4 for windows (SAS Institute, Cary NC). Where necessary, data was transformed prior to analysis. Significance was determined at $P \leq 0.05$. The PDIFF function of LSMEANS procedures was used to compare means.

\section{Results}

\subsection{Effect of Variety and Nitrogen}

\subsubsection{Yield}

In 2014, fresh stem yield differed with variety $(P<0.05)$ and was significantly affected by $\mathrm{N}$ rate $(P<0.0001)$ which showed a quadratic response effect on yield (Table 2). Unfertilized crop produced $40.4 \mathrm{Mg} \cdot \mathrm{ha}^{-1}$ of fresh stem while application of $40 \mathrm{~kg} \cdot \mathrm{N} \cdot \mathrm{ha}^{-1}$ increased stem yield by $66 \%$ to $67.1 \mathrm{Mg} \cdot \mathrm{ha}^{-1}$. At $\geq 80$ $\mathrm{kg} \cdot \mathrm{N} \cdot \mathrm{ha}^{-1}$ produced similar yields averaged $75.3 \mathrm{Mg} \cdot \mathrm{ha}^{-1}$. Total fresh (stem + leaf) yield at harvest also showed a quadratic response to $\mathrm{N}$ application. The unfertilized crop produced the least total biomass at $45.7 \mathrm{Mg} \cdot \mathrm{ha}^{-1}$ and 120 $\mathrm{kg} \cdot \mathrm{N} \cdot \mathrm{ha}^{-1}$ increased total biomass by $85 \%$. Nitrogen applied at 40 and $80 \mathrm{~kg} \cdot \mathrm{ha}^{-1}$ produced similar total yields of 73.3 and $79.7 \mathrm{Mg} \cdot \mathrm{ha}^{-1}$, respectively. Nitrogen fer- 
Table 2. Fresh biomass of different sweet sorghum varieties in response to nitrogen fertilizer at Randolph farm, Virginia State University.

\begin{tabular}{|c|c|c|c|c|}
\hline \multirow{4}{*}{$\begin{array}{c}\text { Nitrogen } \\
\left(\mathrm{Kg}^{2} \mathrm{~N} \cdot \mathrm{ha}^{-1}\right)\end{array}$} & \multicolumn{4}{|c|}{ Fresh biomass at harvest } \\
\hline & \multicolumn{2}{|c|}{ Stem } & \multicolumn{2}{|c|}{ Total (Stem + Leaves) } \\
\hline & 2014 & 2015 & 2014 & 2015 \\
\hline & \multicolumn{4}{|c|}{$\mathrm{Mg} \cdot \mathrm{ha}^{-1}$} \\
\hline 0 & $40.4^{\mathrm{c} \dagger}$ & $54.8^{\mathrm{c}}$ & $45.7^{\mathrm{c}}$ & $61.8^{c}$ \\
\hline 40 & $67.1^{\mathrm{b}}$ & $60.5^{\mathrm{bc}}$ & $73.3^{\mathrm{b}}$ & $67.0^{\mathrm{bc}}$ \\
\hline 80 & $73.3^{\mathrm{ab}}$ & $70.0^{\mathrm{a}}$ & $79.7^{\mathrm{ab}}$ & $77.7^{\mathrm{a}}$ \\
\hline 120 & $77.3^{\mathrm{a}}$ & $63.4^{\mathrm{ab}}$ & $84.7^{\mathrm{a}}$ & $71.6^{\mathrm{ab}}$ \\
\hline$P$-value & $<0.0001$ & 0.0054 & $<0.0001$ & 0.0045 \\
\hline Linear & $<0.0001$ & 0.0045 & $<0.0001$ & 0.0037 \\
\hline Quadratic & $<0.0001$ & 0.0399 & $<0.0001$ & 0.0850 \\
\hline Cubic & 0.0793 & 0.1555 & 0.0772 & 0.1454 \\
\hline
\end{tabular}

${ }^{\dagger}$ Values for nitrogen rates within a column with same letters are not significantly different at $P=0.05$.

tilizer rate $\geq 80 \mathrm{~kg} \cdot \mathrm{N} \cdot \mathrm{ha}^{-1}$ produced comparable yields averaged at $82.2 \mathrm{Mg} \cdot \mathrm{ha}^{-1}$. Though yield among varieties was not significantly different, there was a 4.3 $M g \cdot \mathrm{ha}^{-1}$ difference between Topper 76-6 CHR-SW8. While leaf contribution to total fresh biomass at harvest was around $7.5 \%$ for Dale and Theis, it was above $9.5 \%$ in the other varieties.

In 2015, biomass yield was significantly affected $\mathrm{N}$ fertilizer rate $(P<0.01)$ and variety $(P<0.01)$. Like in 2014 , stem yield showed a quadratic response to $\mathrm{N}$ fertilizer application rate (Table 2). Unfertilized crop produced $54.8 \mathrm{Mg} \mathrm{ha}^{-1}$ of fresh stems while at $\geq 80 \mathrm{~kg} \cdot \mathrm{N} \cdot \mathrm{ha}^{-1}$, stem biomass averaged $66.7 \mathrm{Mg} \cdot \mathrm{ha}^{-1}$. The total biomass had similar trend to that of stem only, with $\mathrm{N}$ fertilizer at $120 \mathrm{~kg} \cdot \mathrm{ha}^{-1}$ producing greater yield than unfertilized crop. Unlike in 2014, stem and total biomass were significantly lower for Dale compared to CHR-SW8 (Table 3). Like in 2014, proportion of leaf in Dale and Theis was low at below $8.5 \%$ while it was above $10 \%$ in all other varieties.

\subsubsection{Juice Volume}

In 2014, juice yield was affected by $\mathrm{N}$ rate application $(P<0.02)$ and differed with variety $(P=0.05)$. Juice volume increased linearly with $\mathrm{N}$ rate (Table 4$)$, with the least juice yield of $14,595 \mathrm{~L} \cdot \mathrm{ha}^{-1}$ obtained in the unfertilized crop., Nitrogen fertilized crop produced greater juice yield averaged at $18,813 \mathrm{~L} \cdot \mathrm{ha}^{-1}$. Although Topper 76-6 produces the least juice yield $\left(13,094 \mathrm{~L} \cdot \mathrm{ha}^{-1}\right)$ compared to Dale and Theis, the volume was similar to that of CHR-SW8 and M81E. Of the four varieties with similar juice yield, Dale produces a relatively greater amount of $22,431 \mathrm{~L} \cdot h \mathrm{~h}^{-1}$.

Although juice yield showed an increasing trend with $\mathrm{N}$ rate in 2015, volume were similar within the range of $\mathrm{N}$ fertilizer rate. The lowest volume was obtained in crops receiving no $\mathrm{N}$ fertilizer $\left(16,000 \mathrm{~L} \cdot \mathrm{ha}^{-1}\right)$ while fertilized crops produced $2000 \mathrm{~L} \cdot \mathrm{ha}^{-1}$ additional juice (Table 5). Theis and M81E produced the 
Table 3. Fresh biomass of different sweet sorghum varieties at Randolph farm, Virginia State University.

\begin{tabular}{|c|c|c|c|c|}
\hline \multirow{4}{*}{ Variety } & \multicolumn{4}{|c|}{ Fresh biomass at harvest } \\
\hline & \multicolumn{2}{|c|}{ Stem } & \multicolumn{2}{|c|}{ Total (Stem + Leaves) } \\
\hline & 2014 & 2015 & 2014 & 2015 \\
\hline & \multicolumn{4}{|c|}{$\mathrm{Mg} \mathrm{ha}^{-1}$} \\
\hline Topper-76-6 & $59.9^{\dagger}$ & $57.5^{\mathrm{bc}}$ & 66.2 & $68.5^{\mathrm{bc}}$ \\
\hline CHR-SW8 & 63.9 & $67.8^{\mathrm{a}}$ & 71.4 & $76.9^{\mathrm{a}}$ \\
\hline M81E & 63.9 & $65.5^{\mathrm{ab}}$ & 70.9 & $74.2^{\mathrm{ab}}$ \\
\hline Dale & 64.4 & $53.9^{c}$ & 69.7 & $58.3^{\mathrm{c}}$ \\
\hline Theis & 65.9 & $66.4^{\mathrm{ab}}$ & 71.4 & $72.7^{\mathrm{ab}}$ \\
\hline$P$-value & 0.7213 & $<0.0001$ & 0.7910 & $<0.0001$ \\
\hline
\end{tabular}

${ }^{\dagger}$ Values within a column with same letters are not significantly different at $P=0.05$.

Table 4. Juice volume, brix and sugar contents of different sweet sorghum varieties in response to nitrogen fertilizer at Randolph farm, Virginia State University, in 2014.

\begin{tabular}{clccccc}
\hline & & \multicolumn{3}{c}{ Sugar content } \\
\cline { 3 - 6 } Nitrogen & Volume & Brix & Fructose & Glucose & Sucrose & Total sugar \\
\cline { 3 - 6 } & & & \multicolumn{2}{c}{$\mathrm{g} \cdot \mathrm{L}^{-1}$} & \\
\hline
\end{tabular}

\begin{tabular}{ccccccc}
0 & $14595^{\mathrm{b} \dagger}$ & $16.6^{\mathrm{a}}$ & $11.4^{\mathrm{b}}$ & 19.7 & $46.0^{\mathrm{b}}$ & $80.4^{\mathrm{b}}$ \\
40 & $16121^{\mathrm{ab}}$ & $15.3^{\mathrm{c}}$ & $21.4^{\mathrm{a}}$ & 24.6 & $52.8^{\mathrm{b}}$ & $100.7^{\mathrm{a}}$ \\
80 & $16350^{\mathrm{a}}$ & $15.5^{\mathrm{bc}}$ & $21.8^{\mathrm{a}}$ & 26.3 & $69.5^{\mathrm{a}}$ & $119.0^{\mathrm{a}}$ \\
120 & $23969 \mathrm{a}$ & $16.5^{\mathrm{ab}}$ & $22.1^{\mathrm{a}}$ & 29.0 & $46.5^{\mathrm{b}}$ & $100.5^{\mathrm{ab}}$ \\
\cline { 2 - 6 } $\begin{array}{c}\text {-value } \\
\text { Linear }\end{array}$ & 0.0194 & 0.0226 & 0.0202 & 0.0569 & 0.0030 & 0.0131 \\
Quadratic & 0.0033 & 0.6297 & 0.0502 & 0.0155 & 0.7402 & 0.0919 \\
Cubic & 0.0880 & 0.0106 & 0.0556 & 0.4595 & 0.0635 & 0.0321
\end{tabular}

\begin{tabular}{|c|c|c|c|c|c|c|}
\hline Variety & & & & & & \\
\hline Topper-76-6 & $13094^{\mathrm{b} \dagger}$ & 16.8 & 23.3 & 23.7 & $67.1^{\mathrm{a}}$ & 117.8 \\
\hline CHR-SW8 & $15846^{\mathrm{ab}}$ & 15.7 & 17.2 & 20.0 & $59.7^{\mathrm{a}}$ & 98.8 \\
\hline M81E & $18238^{\mathrm{ab}}$ & 15.4 & 18.0 & 22.2 & $67.8^{\mathrm{a}}$ & 108.5 \\
\hline Dale & $22431^{\mathrm{a}}$ & 16.2 & 21.0 & 32.7 & $28.8^{\mathrm{b}}$ & 92.2 \\
\hline Theis & $19032^{\mathrm{a}}$ & 15.8 & 15.1 & 27.8 & $26.9^{\mathrm{b}}$ & 83.1 \\
\hline$P$-value & 0.0321 & 0.1791 & 0.5079 & 0.0571 & $<0.0001$ & 0.1729 \\
\hline
\end{tabular}

${ }^{\dagger}$ Values for nitrogen rates and variety within a column with same letters are not significantly different at $P=$ 0.05 . 
Table 5. Juice volume, brix and sugar contents of different sweet sorghum varieties in response to nitrogen fertilizer at Randolph farm, Virginia State University, in 2015.

\begin{tabular}{|c|c|c|c|c|c|c|}
\hline \multirow{3}{*}{$\begin{array}{c}\text { Nitrogen } \\
\left(\mathrm{Kg} \cdot \mathrm{N} \cdot \mathrm{ha}^{-1}\right)\end{array}$} & \multirow{3}{*}{$\begin{array}{l}\text { Volume } \\
\left(\mathrm{L} \cdot \mathrm{ha}^{-1}\right)\end{array}$} & \multirow{3}{*}{ Brix } & \multicolumn{4}{|c|}{ Sugar content } \\
\hline & & & Fructose & Glucose & Sucrose & Total sugar \\
\hline & & & \multicolumn{4}{|c|}{$\mathrm{g} \cdot \mathrm{L}^{-1}$} \\
\hline 0 & $16078^{\dagger}$ & 14.3 & 17.6 & $25.6^{\mathrm{a}}$ & 38.5 & 82.4 \\
\hline 40 & 18347 & 13.3 & 13.7 & $18.1^{\mathrm{b}}$ & 26.5 & 59.0 \\
\hline 80 & 19799 & 13.1 & 15.0 & $26.2^{\mathrm{a}}$ & 32.1 & 75.0 \\
\hline 120 & 18482 & 13.1 & 18.4 & $24.3^{\mathrm{a}}$ & 33.6 & 77.0 \\
\hline$P$-value & 0.1951 & 0.0678 & 0.2750 & 0.0396 & 0.1038 & 0.0741 \\
\hline Linear & 0.1294 & 0.0298 & 0.5109 & 0.8251 & 0.4466 & 0.8183 \\
\hline Quadratic & 0.1639 & 0.2988 & 0.7953 & 0.3531 & 0.1401 & 0.1767 \\
\hline Cubic & 0.7568 & 0.8019 & 0.1419 & 0.0526 & 0.4671 & 0.2499 \\
\hline \multicolumn{7}{|l|}{ Variety } \\
\hline Topper-76-6 & $16142^{\mathrm{bc} \dagger}$ & $15.3^{\mathrm{a}}$ & $19.7^{\mathrm{a}}$ & $26.1^{\mathrm{a}}$ & $38.9^{\mathrm{a}}$ & $85.1^{\mathrm{a}}$ \\
\hline CHR-SW8 & $18785^{\mathrm{ab}}$ & $13.8^{\mathrm{b}}$ & $18.8^{\mathrm{a}}$ & $25.0^{\mathrm{a}}$ & $36.5^{\mathrm{a}}$ & $80.8^{\mathrm{a}}$ \\
\hline M81E & $20489^{a}$ & $13.0^{\mathrm{bc}}$ & $17.2^{\mathrm{a}}$ & $25.4^{\mathrm{a}}$ & $39.0^{\mathrm{a}}$ & $81.9^{\mathrm{a}}$ \\
\hline Dale & $14787^{c}$ & $13.2^{\mathrm{b}}$ & $17.1^{\mathrm{a}}$ & $28.4^{\mathrm{a}}$ & $35.2^{\mathrm{a}}$ & $83.2^{\mathrm{a}}$ \\
\hline Theis & $20954^{a}$ & $12.1^{\mathrm{c}}$ & $9.0^{\mathrm{b}}$ & $14.1^{\mathrm{b}}$ & $16.6^{\mathrm{b}}$ & $40.3^{\mathrm{b}}$ \\
\hline$P$-value & 0.008 & $<0.0001$ & 0.0059 & 0.0015 & 0.0002 & $<0.0001$ \\
\hline
\end{tabular}

${ }^{\dagger}$ Values for nitrogen rates and variety within a column with same letters are not significantly different at $P=$ 0.05 .

greatest volume of 20,954 and 20,489 L·ha ${ }^{-1}$, respectively. The least juice volume of $14,786 \mathrm{~L} \cdot \mathrm{ha}^{-1}$ produced by Dale was statistically similar to $16,142 \mathrm{~L} \cdot \mathrm{ha}^{-1}$ produced by Topper 76-6.

\subsubsection{Juice ${ }^{\circ}$ Brix and Sugar Content}

In 2014, juice ${ }^{\circ}$ Brix showed no clear relationship to $\mathrm{N}$ fertilizer application with values ranging from 15.3 to 16.6 (Table 4 ). Juice ${ }^{\circ}$ Brix did not differ among varieties and averaged 15.9. Juice from crops receiving 40 or $80 \mathrm{~kg} \cdot \mathrm{N} \cdot \mathrm{ha}^{-1}$, had higher fructose and total sugar than the unfertilized crop (Table 4). Although glucose content showed a linear response to $\mathrm{N}$ fertilizer rate, there were statistically similar within the range of $\mathrm{N}$ rate used. Varieties only showed differences in amount of sucrose $(P<0.001)$. Dale and Theis had the least sucrose content averaged at $28.0 \mathrm{~g} \cdot \mathrm{L}^{-1}$ while the others had similar quantities averaged at 6.49 $\mathrm{g} / 100 \mathrm{ml}$ (Table 4).

The fertilized crop produced juice with numerically lower ${ }^{\circ}$ Brix values in 2015 and the effect of $\mathrm{N}$ application was not significant (Table 5). The juice from non-fertilized crop had a higher ${ }^{\circ}$ Brix value (14.3) while crops receiving some level of $\mathrm{N}$ fertilizer averaged at 13.1 (Table 5). Except for glucose that showed 
significant $\mathrm{N}$ effect with no particular trend, other sugars and total sugar showed no response to $\mathrm{N}$ fertilizer (Table 5). Across $\mathrm{N}$ fertilizer rates, fructose, sucrose and total sugar averaged $16.2,32.7$, and $73.3 \mathrm{~g} \cdot \mathrm{L}^{-1}$, respectively. Varieties showed significant $(P<0.001)$ differences in ${ }^{\circ}$ Brix value with Theis showing the least value (12.1) and Topper 76-6 the greatest value (15.3).

\subsection{The Effect of Panicle Removal}

\subsubsection{Effect on ${ }^{\circ}$ Brix}

${ }^{\circ}$ Brix value were significantly affected $(P<0.05)$ by panicle removal and differed with variety (Table 6$)$, although no interaction $(P=0.07)$ between variety and panicle removal was observed. However, for all varieties, juice obtained from plants with panicles had relatively lower ${ }^{\circ}$ Brix value compared to those without panicles. Across varieties, mean ${ }^{\circ}$ Brix value for plants with panicle was 16.8, a value significantly $(P<0.05)$ lower than the 19.0 shown by juice from plants whose panicles were removed. Among the varieties, Theis had the lowest ${ }^{\circ} \mathrm{Brix}$ value (17.5) compared to that of CHR-SW8 and Topper that averaged a unit higher at 18.4 . In 2015 , a significant interaction $(P<0.001)$ between variety and panicle removal was observed (Table 6). For plants with panicles, Topper had the highest ${ }^{\circ}$ Brix of 16.6 while Theis had the lowest at 13.2. All others had similar ${ }^{\circ}$ Brix values that averaged 14.4. For plants without panicles, Topper had the greatest ${ }^{\circ}$ Brix value (18.1), followed by M81E and CHR-SW8 with ${ }^{\circ}$ Brix value averaging 16.7. Dale and Theis had similar and the least ${ }^{\circ}$ Brix value averaged at 15.9.

Table 6. Brix, sucrose, and total sugar content in juice from different varieties as affected by presence $(+)$ or absence $(-)$ of the panicle.

\begin{tabular}{cccccccc}
\hline & & \multicolumn{2}{c}{${ }^{\circ}$ Brix } & \multicolumn{2}{c}{ Sucrose } & \multicolumn{2}{c}{ Total sugar } \\
\cline { 3 - 7 } Variety & Panicle & 2014 & 2015 & 2014 & 2015 & 2014 & 2015 \\
\cline { 3 - 8 } & & & & \multicolumn{2}{c}{$\mathrm{g} \cdot \mathrm{L}^{-1}$} \\
Topper-76-6 & + & $18.1 \mathrm{~b}^{\dagger}$ & $16.6^{\mathrm{bc}}$ & $61.2^{\mathrm{bc}}$ & $54.5^{\mathrm{bc}}$ & $117.4^{\mathrm{bcde}}$ & $102.3^{\mathrm{ab}}$ \\
CHR-SW8 & + & $16.7^{\mathrm{c}}$ & $14.7^{\mathrm{e}}$ & $68.1^{\mathrm{b}}$ & $46.8^{\mathrm{cd}}$ & $109.1^{\mathrm{de}}$ & $92.1^{\mathrm{b}}$ \\
M81E & + & $16.4^{\mathrm{c}}$ & $14.2^{\mathrm{e}}$ & $61.0^{\mathrm{bc}}$ & $45.0^{\mathrm{cd}}$ & $106.5^{\mathrm{ef}}$ & $91.7^{\mathrm{b}}$ \\
Dale & + & $16.7^{\mathrm{c}}$ & $14.3^{\mathrm{e}}$ & $44.0^{\mathrm{d}}$ & $39.0^{\mathrm{de}}$ & $105.1^{\mathrm{ef}}$ & $95.4^{\mathrm{b}}$ \\
Theis & + & $16.4^{\mathrm{c}}$ & $13.2^{\mathrm{f}}$ & $42.2^{\mathrm{d}}$ & $21.1^{\mathrm{e}}$ & $94.9^{\mathrm{f}}$ & $46.8^{\mathrm{d}}$ \\
Topper-76-6 & - & $20.0^{\mathrm{a}}$ & $18.1^{\mathrm{a}}$ & $85.4^{\mathrm{a}}$ & $73.0^{\mathrm{a}}$ & $143.0^{\mathrm{a}}$ & $121.7^{\mathrm{a}}$ \\
CHR-SW8 & - & $18.7^{\mathrm{b}}$ & $16.4^{\mathrm{bc}}$ & $79.8^{\mathrm{ab}}$ & $69.3^{\mathrm{a}}$ & $133.6^{\mathrm{ab}}$ & $116.2^{\mathrm{a}}$ \\
M81E & - & $18.8^{\mathrm{b}}$ & $17.0^{\mathrm{b}}$ & $68.1^{\mathrm{ab}}$ & $63.5^{\mathrm{ab}}$ & $125.1^{\mathrm{abc}}$ & $109.0^{\mathrm{ab}}$ \\
Dale & - & $18.8^{\mathrm{b}}$ & $15.6^{\mathrm{d}}$ & $66.6^{\mathrm{b}}$ & $31.8^{\mathrm{e}}$ & $121.9^{\mathrm{bcd}}$ & $70.7^{\mathrm{c}}$ \\
Theis & - & $18.6^{\mathrm{b}}$ & $16.2^{\mathrm{cd}}$ & $51.8^{\mathrm{c}}$ & $31.8^{\mathrm{e}}$ & $112.7^{\mathrm{cde}}$ & $64.5^{\mathrm{c}}$ \\
\hline
\end{tabular}

${ }^{\dagger}$ Values within a column with same letters are not significantly different at $P=0.05$. 


\subsubsection{Effect on Glucose, Fructose and Sucrose Content}

In 2014, variety and panicle removal affected the concentration of all simple sugars (data not shown), sucrose, and total sugar in the juice (Table 6). Sucrose and total sugar were greater in crops whose panicles were removed compared to those with panicles. Topper, M81E, and CHR-SW8 had similar sucrose content averaged at $63.0 \mathrm{~g} \cdot \mathrm{L}^{-1}$ that were higher than that of Dale and Theis, at $43.1 \mathrm{~g} \cdot \mathrm{L}^{-1}$. In juice from plants whose panicles were removed, a similar pattern was observed with Topper, M81E, and CHR-SW8 giving similar sucrose content averaged at $77.0 \mathrm{~g} \cdot \mathrm{L}^{-1}$. Dale had sucrose content of $67.0 \mathrm{~g} \cdot \mathrm{L}^{-1}$ that was greater than $52.0 \mathrm{~g} \cdot \mathrm{L}^{-1}$ for Theis, but similar to that of M81E, and CHR-SW8. For plants with panicles, Theis had the least total sugar of $94.9 \mathrm{~g} \cdot \mathrm{L}^{-1}$, while all other varieties had comparable contents averaging $110 \mathrm{~g} \cdot \mathrm{L}^{-1}$. For plants without panicle, total sugar content of $143.0 \mathrm{~g} \cdot \mathrm{L}^{-1}$ in Topper was similar to that of CHR-SW8 and M81E and greater than the $113 \mathrm{~g} \cdot \mathrm{L}^{-1}$ recorded for Theis.

In 2015, simple sugars (data not shown), sucrose and total sugar content were significantly affected by the interaction between variety and panicle removal (Table 6). While all varieties showed an increase in juice sucrose and total sugar content with panicle removal, the percentage increase differed with variety. Plants with panicles, were greatest sucrose content $\left(54.5 \mathrm{~g} \cdot \mathrm{L}^{-1}\right)$ in Topper was similar to that of other varieties except Theis. The least sucrose content of 21.1 $\mathrm{g} \cdot \mathrm{L}^{-1}$ found in Theis was similar to $39.0 \mathrm{~g} \cdot \mathrm{L}^{-1}$ found in Dale. In plants without panicle, Dale and Theis juice had the least sucrose content averaged at $35.4 \mathrm{~g} \cdot \mathrm{L}^{-1}$. All other varieties had greater juice sucrose content averaged at $75.6 \mathrm{~g} \cdot \mathrm{L}^{-1}$. Similarly, in plants with panicles, Theis had the least total sugars at $46.8 \mathrm{~g} \cdot \mathrm{L}^{-1}$, while all other varieties had greater but similar contents averaged at $95.3 \mathrm{~g} \cdot \mathrm{L}^{-1}$. The same trend was seen in plants with without. Dale and Theis had similar and the least amount of total sugar averaged at $67.7 \mathrm{~g} \cdot \mathrm{L}^{-1}$, while all other varieties had similar and greater sugar content averaged at $115.6 \mathrm{~g} \cdot \mathrm{L}^{-1}$. In all years and for each variety, sugar concentration of sugars in plants with panicles were lower than that those without.

\section{Discussion}

Yield obtained for all the varieties studied were within margins of those reported by other researchers [24] [25] [26]. The observed varietal difference in fresh biomass may be a result of genetic differences and resource use efficiency that was not determined in this study. Nitrogen fertilized crop produced more yield than the control during both production years. However, the major increased was with the first increment of $40 \mathrm{~kg} \cdot \mathrm{N} \cdot \mathrm{ha}^{-1}$, a result similar to that previously reported [20] [22]. Though there was yield increased up to $80 \mathrm{~kg} \cdot \mathrm{N} \cdot \mathrm{ha}^{-1}$, the decrease in additional yield per unit of $\mathrm{N}$ may be attributed to diminishing returns. Residual soil $\mathrm{N}$ and mineralized $\mathrm{N}$ from organic matter and preceding crop history may affect $\mathrm{N}$ response [18]. The observed differences in $\mathrm{N}$ response magnitudes between the two years may be attributed to preceding crop effect, a maize crop (2014) and soybean (2015).

The juice yield volume for M81E was comparable to those found in Mexico 
and India [27] [28]. It also compares well with those of six varieties and hybrids evaluated in Nebraska [29]. The respective increase and the relatively higher volume with $\mathrm{N}$ fertilizer in 2014 and 2015 are similar to those reported before [28] and may be a result of an increase in stem biomass. The low juice yield in Dale in 2015 may be due to observed low fresh stem biomass. The juice ${ }^{\circ}$ Brix values were similar to those reported elsewhere [13] [22]. The positive response to $\mathrm{N}$ in sugar content in 2014 is in line with increase in water soluble sugars with $\mathrm{N}$ fertilizer reported earlier [30]. The relatively high quantitative values for soluble sugar in 2014 compared to 2015 may be due differences in rainfall amounts. The summer of 2014 was drier than 2015 (Table 1) and may have led to increased soluble sugar production as earlier reported for water stress sweet sorghum that produced $29 \%$ more hexose sugars than a well-watered crop [31]. Differences in sucrose levels among the varieties may be due to differences in the expression of the amylase enzyme, a possible scenario especially given that varieties with high sucrose had lower glucose content. Sucrose and total sugar were slightly lower than those reported by others [6] [27] [32] [33].

The increase in ${ }^{\circ}$ Brix with head removal observed is similar to previous reports [12] [13]. Despite previous studies showing that stem sugar accumulation post-anthesis is minimal [34], increase in sucrose with panicle removal in this study is similar to other findings where a $13 \%$ increase in sugar occurred with head removal in M-81E [13]. Increase in ${ }^{\circ}$ Brix and sugar content in stems with male sterility has also been reported [12]. These two studies show the potential benefit of pollen sterility and non-seed formation on sugar concentration in the stem. Manipulation of the plant like removal of panicle is reported to alter nutrient partitioning and relocation in plants [35] because developing seeds are sinks for photosynthates during the grain filling phase [36]. In fact, the resultant grain starch from soluble sugars that reach the seed can be as high as 200 to 555 $\mathrm{g} \cdot \mathrm{kg}^{-1}$ of grain weight [37]. Therefore, panicle removal at seeding phase as done in this study allowed sugars to be redirected to the stems and most likely responsible for the greater juice sugar content obtained.

\section{Conclusion}

In conclusion, the tested varieties showed good potential for production in the mid-Atlantic. Nitrogen fertilizer increased fresh biomass and juice yield while panicle removal increased sugar concentration in extracted juice. Beside these management strategies, selecting varieties that are shorter and which anchored firmly on to the soil and with low susceptibility to stalk borer may help reduce lodging associated biomass losses. While greater volume may compensate low sugar concentration, extraction of the additional juice increases the costs. Therefore, future research should target varieties with inherently high sugar content for improvement and subsequent recommendation to producers.

\section{Acknowledgements}

The authors are grateful to the USDA Evans-Allen program for funding the 
study. We are also grateful to the management at the Agriculture Research Station, Virginia State University, for logistical, material and human resource support. Contribution of Virginia State University, Agricultural Research Station, Journal Article Series No. 336.

\section{References}

[1] Hons, F.M., Moresco, R.F., Wiedenfeld, R.P. and Cothren, J.T. (1986) Applied Nitrogen and Phosphorus Effects on Yield and Nutrient Uptake by High Energy Sorghum Produced for Grain and Biomass. Agronomy Journal, 76, 1069-1078. https://doi.org/10.2134/agronj1986.00021962007800060026x

[2] Zegada-Lizarazu, W., Zatta, A. and Monti, A. (2012) Water Uptake Efficiency and Above and Belowground Biomass Development of Sweet Sorghum and Maize under Different Water Regimes. Plant Soil, 351, 47-60. https://doi.org/10.1007/s11104-011-0928-2

[3] Miller, F.R. and Creelman, R.A. (1980) Sorghum. A New Fuel. The American Seed Trade Association Annual Corn Sorghum Research Conference, Chicago, 9-11 December 1980, 219-232.

[4] Woods, J. (2001) The Potential for Energy Production Using Sweet Sorghum in Southern Africa. Energy for Sustainable Development, 5, 31-38.

[5] Gnansounou, E., Dauriat, A. and Wyman, C.E. (2005) Refining Sweet Sorghum to Ethanol and Sugar: Economic Trade-Offs in the Context of North China. Bioresource Technology, 96, 985-1002. https://doi.org/10.1016/j.biortech.2004.09.015

[6] Prasad, S., Singh, A., Jainand, N. and Joshi, H.C. (2007) Ethanol Production from Sweet Sorghum Syrup for Utilization as Automotive Fuel in India. Energy Fuels, 21, 2415-2420. https://doi.org/10.1021/ef060328z

[7] Propheter, J.L. and Straggenborg, S. (2010) Performance of Annual and Perennial Biofuel Crops. Yield during the First Two Years. Agronomy Journal, 102, 806-814. https://doi.org/10.2134/agronj2009.0301

[8] Hills, F.J., Lewellen, R.T. and Skoyen, I.O. (1990) Sweet Sorghum Cultivars for Alcohol Production. California Agriculture, 14, 14-16.

[9] Putnam, D.H., Lueschen, W.E., Kanne, B.K. and Hoverstad, T.R. (1991) A Comparison of Sweet Sorghum Cultivars and Maize for Ethanol Production. Journal of Production Agriculture, 4, 377-381. https://doi.org/10.2134/jpa1991.0377

[10] Grassi, G. (2001) Sweet Sorghum: One of the Best World Food-Feed-Energy Crops.

[11] Reddy, B.V.S., Kumar, A.A. and Ramesh, S. (2007) Sweet Sorghum: A Water Saving Bio-Energy Crop. International Conference on Linkages Between Energy and Water Management for Agriculture in Developing Countries, IWMI, International Crops Research Institute for Semi-Arid Tropics (ICRISAT) Campus, Hyderabad, 29-30 January 2007, 1-12.

[12] Pfeiffer, T.W., Bitzer, M.J., Toy, J.J. and Pedersen, J.F. (2010) Heterosis in Sweet Sorghum and Selection of a New Sweet Sorghum Hybrid for Use in Syrup Production in Appalachia. Crop Science, 50, 1788-1794.

https://doi.org/10.2135/cropsci2009.09.0475

[13] Erickson, J.E., Woodard, K.R. and Sollenberger, L.E. (2011) Optimizing Sweet Sorghum Production for Biofuel in the Southeastern USA through Nitrogen Fertilization and Top Removal. BioEnergy Research, 5, 86-94.

[14] Zhao, Y.L., Dolat, A., Steinberger, Y., Wang, X., Osman, A. and Xie, G.H. (2009) Biomass Yield and Chemical Composition of Sweet Sorghum Cultivars Grown for 
Biofuel. Crop Science, 111, 55-64. https://doi.org/10.1016/j.fcr.2008.10.006

[15] Dalvi, U.S., Chavan, U.D., Shinde, M.S. and Gadakh, S.R. (2011) Assessment of Sweet Sorghum Cultivars for Efficient Ethanol Production. Sugar Tech, 13, 186-190. https://doi.org/10.1007/s12355-011-0094-0

[16] Sipos, B., Réczey, J., Somorai, Z., Kádár, Z., Dienes, D. and Réczey, K. (2009) Sweet Sorghum as Feedstock for Ethanol Production: Enzymatic Hydrolysis of SteamPretreated Bagasse. Applied Biochemistry and Biotechnology, 153, 151-163. https://doi.org/10.1007/s12010-008-8423-9

[17] Monti, A. and Venturi, G. (2003) Comparison of the Energy Performance of Fiber Sorghum, Sweet Sorghum, and Wheat Monocultures in Northern Italy. European Journal of Agronomy, 19, 35-43. https://doi.org/10.1016/S1161-0301(02)00017-5

[18] Bitzer, M.J. (1997) Production of Sweet Sorghum for Syrup in Kentucky. AGR-122, University of Kentucky Cooperative Extension Service, Burkesville, 4.

[19] Vermerris, W., Rainbolt, C., Wright, D. and Newman, Y. (2007) Production of Biofuel Crops in Florida: Sweet Sorghum. SS-AGR-293, University of Florida, Institute of Food and Agricultural Sciences, Gainesville, 4.

[20] Holou, R.A.Y. and Stevens, G. (2012) Juice, Sugar, and Bagasse Response of Sweet Sorghum (Sorghum bicolor (L.) Moench cv. M81E) to N Fertilizer and Soil Type. GCB Bioenergy, 4, 302-310. https://doi.org/10.1111/j.1757-1707.2011.01126.x

[21] Johansen, H.N., Glitsø, V. and Knudsen, K.E.B. (1996) Influence of Extraction Solvent and Temperature on the Quantitative Determination of Oligosaccharides from Plant Materials by High-Performance Liquid Chromatography. Journal of Agricultural and Food Chemistry, 44, 1470-1474. https://doi.org/10.1021/jf950482b

[22] Han, K.J., Pitman, W.D., Alison, M.W., Harrel, D.I., Viator, H.P., et al. (2012) Agronomic Consideration for Sweet Sorghum Biofuel Production in the SouthCentral USA. BioEnergy Research, 5, 748-758. https://doi.org/10.1007/s12155-012-9185-3

[23] Yang, L., Dun, B.Q., Zhao, X.I., Yue, M.Q., Ming, L. and Li, G.Y. (2013) Correlation Analysis between the Key Enzymes and Sugar Content in Sweet Sorghum (Sorghum bicolor L. Moench) Stems at Physiological Maturity Stage. Australian Journal of Crop Science, 7, 84-92.

[24] Wortmann, C.S., Liska, A.J., Ferguson, R.B, Lyon, D.J., Klein, R.N. and Dweikat, I. (2010) Dryland Performance of Sweet Sorghum and Grain Crops for Biofuel in Nebraska. Agronomy Journal, 102, 319-326. https://doi.org/10.2134/agronj2009.0271

[25] Venturi, P. and Venturi, G. (2003) Analysis of Energy Comparison for Crops in European Agricultural Systems. Biomass and Bioenergy, 25, 235-255. https://doi.org/10.1016/S0961-9534(03)00015-1

[26] Cifuentes, R., Bressani, R. and Rolz, C. (2014) The Potential of Sweet Sorghum as a Source of Ethanol and Protein. Energy for Sustainable Development, 21, 13-19.

[27] Davila-Gomeza, F.J., Chuck-Hernandeza, C., Perez-Carrilloa, E., Rooney, W.L. and Serna-Saldivara, S.O. (2011) Evaluation of Bioethanol Production from Five Different Varieties of Sweet and Forage Sorghums (Sorghum bicolor (L.) Moench). Industrial Crops and Products, 33, 611-616.

https://doi.org/10.1016/j.indcrop.2010.12.022

[28] Uchino, H., Watanabe, T., Ramu, K., Sahrawat, K.L., Marimuthu, S., Wani, S.P. and Ito, O. (2013) Effect of Nitrogen Application on Sweet Sorghum (Sorghum bicolor (L.) Moench) in the Semi-Arid Tropical Zone of India. Japan Agricultural Research Quarterly, 47, 65-73. https://doi.org/10.6090/jarq.47.65

[29] Perdesen, J.F., Satter, S.E. and Anderson, W.E. (2013) Evaluation of Public Sweet 
Sorghum A-Lines for Use in Hybrid Production. BioEnergy Research, 6, 91-102. https://doi.org/10.1007/s12155-012-9231-1

[30] Thivierge, M.N., Chantigny, M.H., Bélanger, G., Segun, P., Bertrand, A., et al., (2015) Response to Nitrogen of Sweet Pearl Millet and Sweet Sorghum Grown for Ethanol in Eastern Canada. BioEnergy Research, 8, 807-820. https://doi.org/10.1007/s12155-014-9558-x

[31] Geng, S., Hills, F.J., Johnson, S.S. and Sah, R.N. (1989) Potential Yields and OnFarm Ethanol Production Cost of Corn, Sweet Sorghum, Fodder Beet, and Sugar Beet. Journal of Agronomy and Crop Science, 162, 21-29. https://doi.org/10.1111/j.1439-037X.1989.tb00683.x

[32] Rao, S.S., Patil, J.V., Reddy, D.C., Kumar, B.S.V., Rao, P.S., et al. (2013) Effect of Different Crushing Treatments on Sweet Sorghum Juice. Sugar Tech, 15, 311-315. https://doi.org/10.1007/s12355-013-0220-2

[33] Iman, T. and Capereda, S. (2011) Fermentation Kinetics and Ethanol Production from Different Sweet Sorghum Varieties. International Journal of Agricultural and Biological Engineering, 4, 33-40.

[34] Gutjahr, S., Vaksmann, M., Dingkuhn, M., Thera, K., Trouche, G., et al. (2013) Grain, Sugar and Biomass Accumulation in Tropical Sorghums. I. Trade-Offs and Effects of Phenological Plasticity. Functional Plant Biology, 40, 342-354. https://doi.org/10.1071/FP12269

[35] Lin, J.Y. and Lin, J.L. (1994) Post-Heading Partitioning Dynamics of Total Nonstructural Carbohydrates in Rice Plants as Influenced by Sink Manipulation. Journal of the Agricultural Association of China, 165, 53-59.

[36] Slewinski, T.L. (2012) Non-Structural Carbohydrate Partitioning in Grass Stems: A Target to Increase Yield Stability, Stress Tolerance, and Biofuel Production. Journal of Experimental Botany, 63, 4647-4670. https://doi.org/10.1093/jxb/ers124

[37] Rutto, L.K., Xu, Y., Brandt, M., Ren, S. and Kering, M.K. (2013) Juice, Ethanol and Grain Yield Potential of Five Sweet Sorghum (Sorghum bicolor (L.) Moench) Cultivars. Journal of Sustainable Bioenergy Systems, 3, 113-118.

https://doi.org/10.4236/jsbs.2013.32016

Submit or recommend next manuscript to SCIRP and we will provide best service for you:

Accepting pre-submission inquiries through Email, Facebook, LinkedIn, Twitter, etc. A wide selection of journals (inclusive of 9 subjects, more than 200 journals)

Providing 24-hour high-quality service

User-friendly online submission system

Fair and swift peer-review system

Efficient typesetting and proofreading procedure

Display of the result of downloads and visits, as well as the number of cited articles

Maximum dissemination of your research work

Submit your manuscript at: http://papersubmission.scirp.org/

Or contact jsbs@scirp.org 